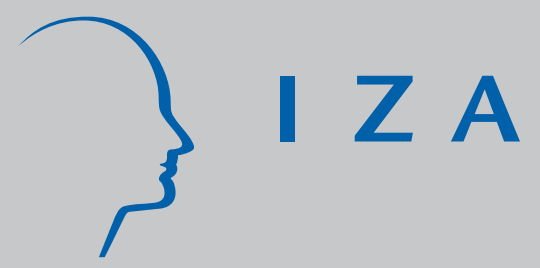

IZA DP No. 577

Are the More Educated Receiving More Training? Evidence from Thailand

Kenn Ariga

Giorgio Brunello

September 2002 


\title{
Are the More Educated Receiving More Training? Evidence from Thailand
}

\author{
Kenn Ariga \\ Kyoto University \\ Giorgio Brunello \\ University of Padova, CESifo and IZA Bonn
}

\author{
Discussion Paper No. 577 \\ September 2002
}

\author{
IZA \\ P.O. Box 7240 \\ D-53072 Bonn \\ Germany \\ Tel.: +49-228-3894-0 \\ Fax: +49-228-3894-210 \\ Email: iza@iza.org
}

This Discussion Paper is issued within the framework of IZA's research area Internationalization of Labor Markets. Any opinions expressed here are those of the author(s) and not those of the institute. Research disseminated by IZA may include views on policy, but the institute itself takes no institutional policy positions.

The Institute for the Study of Labor (IZA) in Bonn is a local and virtual international research center and a place of communication between science, politics and business. IZA is an independent, nonprofit limited liability company (Gesellschaft mit beschränkter Haftung) supported by the Deutsche Post AG. The center is associated with the University of Bonn and offers a stimulating research environment through its research networks, research support, and visitors and doctoral programs. IZA engages in (i) original and internationally competitive research in all fields of labor economics, (ii) development of policy concepts, and (iii) dissemination of research results and concepts to the interested public. The current research program deals with (1) mobility and flexibility of labor, (2) internationalization of labor markets, (3) welfare state and labor market, (4) labor markets in transition countries, (5) the future of labor, (6) evaluation of labor market policies and projects and (7) general labor economics.

IZA Discussion Papers often represent preliminary work and are circulated to encourage discussion. Citation of such a paper should account for its provisional character. A revised version may be available on the IZA website (www.iza.org) or directly from the author. 
IZA Discussion Paper No. 577

September 2002

\section{ABSTRACT}

\section{Are the More Educated Receiving More Training? Evidence from Thailand ${ }^{*}$}

This paper investigates the relationship between education and training provided by the firm, both on the job and off the job, using a unique dataset based on a survey of Thai employees conducted in the summer of 2001. We find a significant and negative relationship between educational attainment and on the job training and no significant relationship between education and off the job training. We also find that education and training are technical complements, especially in the case of off the job training. These findings are consistent with more educated individuals having higher marginal costs of training than less educated workers, especially when on the job training is concerned. Either the better educated have lower learning skills in jobs requiring on the job training or they have higher opportunity costs of training, or both.

JEL Classification: J24, J31

Keywords: training, education, wages

Corresponding author:

Giorgio Brunello

Department of Economics

University of Padova

Via del Santo 33

I - 35121 Padova

Tel.: + 39 (0) $49827-4223$

Fax: +39 (0) $49827-4211 / 4221$

Email: brunello@decon.unipd.it

\footnotetext{
* The current paper is part of a larger research project on "Training and Education in Southeast Asia", funded by the Asian Development Bank Research Institute. We are grateful to the project members, to Futoshi Yamauchi and to the audience in Osaka (KISER), Kyoto and Tokyo (ADBI) for comments and suggestions. This paper was written while the second author was visiting Kyoto University. The usual disclaimer applies.
} 


\section{Introduction}

The economic literature emphasizes strongly the importance of schooling in increasing productivity, improving health and nutrition and reducing fertility (see Behrman [1987]). Schooling can affect productivity both directly, by improving basic skills, and indirectly, by affecting training. Do the better educated receive by firms more or less training? A positive association between education and training has two implications. If the more educated also receive more training, both on the job and off the job, an increase in the average level of educational attainment leads to even higher human capital and productivity. On the other hand, initial individual differences in the level of human capital are bound to widen in the labor market.

The economic literature does not provide a clear-cut answer to the question above. A strand of literature going back to the mid 1970s argues in a rather informal way that more education leads to more training. According to Thurow [1975] and Rosen [1976], education improves learning skills, thereby reducing (marginal) training costs. Since optimal investment in training obtains when marginal costs are equal to marginal benefits, a reduction in marginal costs given marginal benefits increases investment. A more recent strand does not fully support this view. According to Sicherman [1990] and Hersch [1991], over - educated individuals receive less on the job training than individuals with less education. This happens because the over - educated are less willing, or less able, to learn, which increases (marginal) costs of training, thereby leading to lower training incidence.

Clearly, education does not affect only the marginal costs of training. If education and training are technical complements in the production of human capital, an increase in attained education increases the productivity of training and positively affects marginal benefits. Given marginal costs, higher education leads to higher training incidence.

The purpose of this paper is to investigate in an empirical way the relationship between education and training provided by the firm, both on the job and off the job, using a unique dataset based on a survey of Thai employees conducted by a team led by one of the authors during the summer of 2001 . The survey covers 1737 employees belonging to 20 large firms operating in four selected industries in the Bangkok area. These employees filled a questionnaire especially designed to elicit information on earnings, education, training and family background. The availability of information on the last three variables is an important feature of these data. Failure to control for family connections and ability could lead to spurious associations between schooling, training and earnings. 
We distinguish between two types of training, on the job and off the job, and show that only the former type is significantly related to educational attainment. In particular, we find that individuals with more education are less likely to receive on the job training. Therefore, our data provide little support to the view that more education leads to more training. If anything, we find support for the contrary. We also find some evidence that education and training are technical complements, especially in the case of off the job training. In order to explain our empirical results, we need to assume that more educated individuals have higher, not lower, marginal costs of training, especially when on the job training is concerned. Either the better educated have lower learning skills in jobs requiring on the job training or they have higher opportunity costs of training, or both.

The paper is organized as follows. Section 2 introduces two economic models in which to highlight the relationship between education and training. Section 3 presents the data and Section 4 discusses the econometric specification. Empirical results are shown in Section 5 and discussed in Section 6, which also concludes.

\section{Theory}

The purpose of this section is to introduce the concept of technical complementarity between education and training and to investigate how it relates to the co-movement, across individuals and over time, of these two variables. We use two simple models, Model A and Model B. While the first model is static, the second model is dynamic.

\section{Model A}

Consider the following production function

$$
Y=L H
$$

where $Y$ is output and $H$ is the stock of human capital accumulated by each (identical) employee, and let this stock be an increasing function of both education $E$ and training $T$

$$
H=\phi(E, T)
$$


Technical complementarity between education and training is defined by the additional condition

$$
\phi_{T E}>0
$$

which says that an increase in education raises the marginal productivity of training. With no depreciation, the stock of training $T$ in each period of time is simply

$$
T=t+T_{-1}
$$

where $t$ is training during the period and $T_{-1}$ is the stock at the beginning of each period.

Training is costly both to the employer and to the employee. We ignore the interesting issues associated to the allocation of these costs to the parties and define net output per head as

$$
N Y=\phi(E, T)-\sigma(E, T)
$$

where $\sigma(E, T)$ is the cost of training per head, that we assume to vary both with the stock of training $T$ and with the level of education $E$. One possible reason why training costs vary with education is that the better educated have higher learning skills, which reduces the cost of training them compared with the less educated.

Conditional on previous training $T_{-1}$, the optimal level of investment is obtained by maximizing net output. The solution is the same if the program [5] is replaced by an enforceable efficient contract between a firm and a worker, designed to maximize profits subject to a participation constraint. The first order condition associated to this problem is simply

$$
\phi_{T}(E, T)-\sigma_{T}(E, T)=0
$$

where the subscript indicates the partial derivative with respect to training. Using a double subscript for the second partial derivatives, total differentiation of the first order condition yields

$$
\frac{\partial T}{\partial E}=\frac{\sigma_{T E}-\phi_{T E}}{\phi_{T T}-\sigma_{T T}}
$$


This condition clarifies that technical complementarity does not necessarily imply that better educated individuals receive more training. To see why, notice first that the denominator in [7] is negative to fulfil the second order conditions. An increase in education leads to more training only if $\sigma_{T E}-\phi_{T E}<0$. If the marginal cost of training increases with education faster than the marginal product of training, better educated individuals end up with less training even in the presence of technical complementarity ${ }^{1}$.

\section{Model B}

One problem with model $\mathrm{A}$ is that the relationship between training costs and education is not well specified. One could argue, as we have done above, that more education reduces (marginal) training costs. While this argument has some natural appeal, one could also argue that too much education reduces the willingness to undertake training, especially in jobs that are not well suited to the education attained.

An alternative way of thinking about how education affects marginal costs is to emphasize the opportunity costs of training. By undertaking training, an individual is giving up current production to increase future production. In equilibrium, the optimal training policy must balance the marginal costs and the marginal benefits of the additional investment. Consider a single (representative) employee and assume a working life lasting $H$ periods. In each period, the employer and the employee efficiently choose how much time to devote to additional training $t$, that we normalize to lie in the $(0,1)$ range. Current production depends on education and previously accumulated human capital via training, and future production depends on the current training investment.

Define the present discounted value of total net output as

$$
V=\sum_{h=1}^{H} \beta^{h-1}\left(1-t_{h}\right) \phi_{h}
$$

where $\mathrm{h}$ is time, $\beta$ the discount factor,

$$
\phi_{h}=\phi\left(E, T_{h-1}\right)
$$

\footnotetext{
${ }^{1}$ The model can be easily extended to include two types of training.
} 
is real output per head and

$$
T_{h}=\rho T_{h-1}+I_{h}
$$

is accumulated training, with $\rho$ as the depreciation rate of human capital.

Clearly, training investment in the final period $(h=H)$ is zero, as the cost cannot be recouped. In the previous to the last period, however, optimal investment is obtained by maximizing

$$
\left(1-t_{H-1}\right) \phi\left(E, T_{H-2}\right)+\beta \phi\left(E, \rho T_{H-2}+t_{H-1}\right)
$$

with respect to $t_{H-1}$. In this case, the first order condition is

$$
\phi\left(E, T_{H-2}\right)=\beta \eta\left(E, \rho T_{H-2}+t_{H-1}\right)
$$

where

$$
\eta\left(E, \rho T_{H-2}+t_{H-1}\right)=\frac{\partial \phi\left(E, \rho T_{H-2}+t_{H-1}\right)}{\partial t_{H-1}}
$$

Similarly, the first order condition for $h=H-2$ is

$$
\phi\left(E, T_{H-3}\right)=\beta\left[\left(1-t_{H-1}\right) \eta\left(E, \rho T_{H-3}+t_{H-2}\right)+\beta \rho \eta\left(E, \rho T_{H-2}+t_{H-1}\right)\right.
$$

Making use of repeated substitutions in the first order conditions, it can be checked that [14] applies to all earlier periods as well.

Assuming that the real wage $W$ is proportional to output per head ${ }^{2}$, we can re-write the above condition as

$$
W_{h}=\beta\left[\left(1-t_{h+1}\right) \frac{\partial W_{h+1}}{\partial t_{h}}+\beta \rho W_{h+1}\right]
$$

The left - hand side represents the marginal cost and the right - hand side is the marginal benefit of training. An increase in education can affect both marginal costs and marginal benefits. First, there is abundant empirical evidence that more education leads to higher wages (see Card [1999]), implying that 
it is more costly to train an educated worker. Second, higher education increase future marginal benefits if education and training are technical complements, that is, if

$$
\frac{\partial W_{h+1}}{\partial t_{h} \partial E}=\frac{\partial \phi\left(E, T_{h-1}\right)}{\partial t_{h} \partial E}>0
$$

To further illustrate, consider a two - period version of the above model. Because of the second order conditions for a maximum, the marginal benefits schedule must be downward sloping with respect to training $T$. Since the current wage depends on previous training, the marginal cost schedule is flat. Equilibrium investment is shown in Figure 1 below.

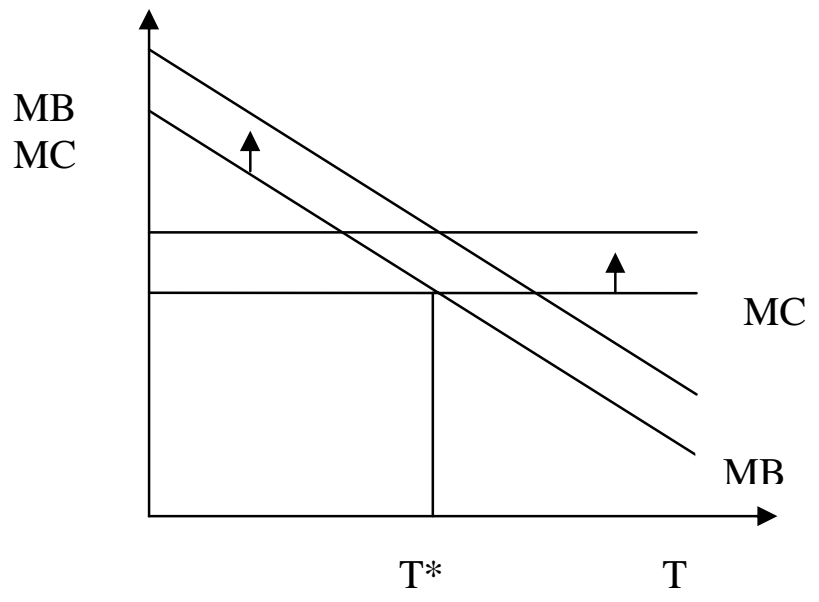

Figure 1

In the presence of technical complementarity, higher education shifts both the marginal costs and the marginal benefits schedule upwards, with a positive effect on wages but uncertain effects on training investment and training incidence. A key insight provided by the models in this section is that technical complementarity is not sufficient to guarantee a positive relationship between education and training.

\footnotetext{
${ }^{2}$ This assumption holds in a Nash bargaining setup where training costs are proportional to output per head.
} 


\section{The Data}

The employee survey on which our data are based covers firms belonging to four industries: food processing, auto parts, hard disk drive makers and computer components (mainly IC). The latter two industries are high tech and dominated by foreign subsidiaries. Thailand is one of the largest production locations for hard disk drives and related components, and this industry is one of the country's major exporters (see Doner and Brimble [1998]). The former two industries use more labor intensive production technologies and include a substantial share of domestic firms.

Despite being hi-tech, HDD and IC/PC firms are also fairly labor intensive, as production gets outsourced in Thailand from abroad to take advantage of the favorable price of labor. In the HDD industry, production involves mainly head stack and head gimbals assembly, which are very labor intensive. Final HDD assembly is usually done in China.

The selection of these industries provides a reasonable coverage of Thai industry without pretending to produce a statistically representative sample. Due to financial constraints, we have restricted our attention to firms with plants located in the Greater Bangkok area. Firms in the four industries were approached and asked too cooperate to the survey. Overall, 20 firms agreed to cooperate, 5 in food processing, 5 in auto parts, 6 in personal computers and 4 in the HDD industry. The firms in the sample have more than 100 employees (more than 1000 in the HDD industry). After restricting our sample to production workers, technicians and engineers, we stratified employment in each firm by age and education and randomly sampled employees within each cell, using larger weights for smaller firms.

Each selected employee was interviewed by trained personnel hired by the Thailand Development Research Institute (TDRI), which cooperated to the project. Since the questionnaire is rather lengthy (121 questions), individual interviews lasted on average 40 minutes. The questionnaire asks detailed information about family background, education, previous job experience, job allocation, training and monthly labor income net of bonuses but gross of overtime. Some of these questions are asked not only for the reference period of the survey (year 2001) but also for the years 1998 to 2000. The timing of some of the retrospective questions is framed to generate predetermined variables. To illustrate, monthly wages were asked with reference to January of each year, and the questions on the occurrence of training referred to the full year. Therefore, training in 1999 could be considered as predetermined with respect to wages in 2000, which were measured in January 2000.

While we acknowledge that recall data are affected by different types of measurement error (see Beckett et al [2001]), we stress that many of these questions are qualitative (requiring only a yes or no 
answer). We also stress that the relative short span of recall is likely to reduce the relative importance of these errors. Overall, our sample provides a snapshot of events for an important group of Thai employees. It is not, however, a statistically representative sample, both because of the selection of industries and because of the endogenous selection associated with the participation of firms to the project. These limits, induced mainly by financial constraints, need to be weighted against the advantages, which include the collection of detailed current and retrospective information on family background, education and different types of training. This information is not readily available from nationally representative labor surveys.

Compared to the entire Thai labor force, our sample is substantially more educated. Table 1 shows the distribution of employment by education and industry in the sample (columns 1 to 4 ) and in the total labor force. The share of employees with primary education in our sample is close to zero in three industries out of four and significantly different from zero only in the food processing industry. In Thailand as a whole, this share is as high as 75 percent $^{3}$. On the other hand, college graduates are 44 percent of all employees in the personal computers industry and only 9 percent in the national average.

Table 1. Distribution of employees by education. By industry and overall.

(1)

$\begin{array}{lll}\text { primary } & 0.36 & 0.00 \\ \text { second. } & 0.41 & 0.55 \\ \text { tertiary } & 0.22 & 0.44\end{array}$

(3)

0.03

0.62

0.34
(4)

0.03

0.62

0.35

\section{(5)}

0.75

0.16

0.09

Notes: second: lower and upper secondary education. (1): foodstuffs; (2):

Electronics; (3): auto components; (4): HDD components; (5) national average (OECD).

These drastic differences are accounted by the fact that we are selecting industries with more than 100 employees, where the average age of employees is close to 28 years. Moreover, the national average includes agricultural employment, where average educational attainment is very low.

Table 2 presents the summary statistics of the main variables in the survey for the year 2001, separately for males and females. Average age of sampled employees is about 28 years, and average tenure in 1998 (ten98), the start of the reference period, is about 2 and a half years for males and slightly 
over 3 years for females. On the other hand, previous labor market experience recorded at the start of the period (exp98) is close to 2 years for both males and females.

The survey asks individuals about their highest attained degree. We convert the answers in years of education by applying to each degree the required number of years of schooling ${ }^{4}$. Average years of attained education is close to 13 years for males and to 11 years for females. Therefore, females in the sample have less education but longer tenure. On the other hand, males have changed more jobs (njobs) during their previous labor market experience (1.11 versus 0.92 jobs).

We collect information both about on the job (OJT) and off the job (OFFJT) training provided by the firm. The former includes both formal and informal training carried out on the job, and focuses mainly on the performance of daily tasks. The latter is formal training carried out off the job and organized by the firm either in or outside the premises, and either during or after standard working hours. While OJT is provided mainly by senior workers in the same unit, team leaders and foremen ( $72 \%$ of the total), OFFJT is supplied mainly by instructors from professional training centres and from outside the company ( $86 \%$ of the total) and concerns both daily tasks, quality standards and safety regulations.

For each type of training, the survey whether the employee has had any training during the reference period (the year), a simple $(0,1)$ dummy, and about training frequency. The latter question is framed differently depending on whether we consider OJT or OFFJT. In the former case we ask the number of training events per year. In the second case we ask the employee to rank the frequency of events in different categories (daily, once a week...). In the final coding we measure OJT frequency as a discrete variable taking the values 0 to 3, with zero for no training and three for the highest frequency. The difference in the question about frequency can be explained with the fact that OJT includes both formal and informal events, and is therefore more difficult to grasp with precision than OFFJT, which takes place outside the work premises.

Starting with training incidence in 2001 (ojt for on the job and off for off the job), we find that $55 \%$ of the males in the sample have undertaken some OJT in 2001, compared to $67 \%$ of the females. Interestingly, the opposite holds for OFFJT, with $67 \%$ of the males and $58 \%$ of the females receiving it. When we cumulate training events over the entire period (1998-2001) by summing up the dummies for each year ${ }^{5}$, however, we find that off the job training incidence over the four years (soff) is about the

\footnotetext{
${ }^{3}$ Clearly such a high percentage discounts the important role played by agriculture.

${ }^{4}$ We set 0 years for no education, 6 years for primary, 9 years for lower secondary, 12 years for upper secondary and lower vocational, 14 years for upper vocational and 16 years for college or more.

${ }^{5}$ We compute sojt as the sum of ojt, a $(0,1)$ dummy, over the relevant sample period. For instance, sojt in 1999 is the sum of ojt in 1998 and 1999, and is equal to 2 is training occurred in both years, to 1 if training occurred in only one year and to zero if training never occurred.
} 
same for males and females. The difference still remains, however, when we consider cumulated on the job training (sojt).

Table 2. Means and standard deviations of the main variables by gender. 2001

\begin{tabular}{|c|c|c|c|c|}
\hline \# obs : & \multicolumn{2}{|c|}{$\begin{array}{c}690 \\
\text { males }\end{array}$} & \multicolumn{2}{|c|}{$\begin{array}{c}1047 \\
\text { females }\end{array}$} \\
\hline wage & 14386 & $(8237)$ & 9347 & $(5260)$ \\
\hline $\operatorname{ten} 98$ & 2.59 & $(3.54)$ & 3.29 & $(3.60)$ \\
\hline $\exp 98$ & 2.17 & $(3.44)$ & 2.27 & $(3.72)$ \\
\hline ojt & 0.55 & $(0.49)$ & 0.67 & $(0.46)$ \\
\hline off & 0.67 & $(0.46)$ & 0.58 & $(0.48)$ \\
\hline frojt & 1.00 & $(1.14)$ & 1.18 & $(1.11)$ \\
\hline froff & 2.03 & $(2.91)$ & 1.55 & $(2.41)$ \\
\hline promo & 0.13 & $(0.34)$ & 0.09 & $(0.29)$ \\
\hline sojt & 1.89 & $(1.69)$ & 2.41 & $(1.63)$ \\
\hline soff & 2.30 & $(1.47)$ & 2.33 & (1.47) \\
\hline sfrojt & 3.37 & $(3.86)$ & 4.23 & $(3.92)$ \\
\hline sfroff & 7.92 & $(10.68)$ & 6.69 & $(9.53)$ \\
\hline spromo & 0.47 & $(0.77)$ & 0.31 & $(0.64)$ \\
\hline edyear & 12.90 & $(2.59)$ & 10.67 & $(3.05)$ \\
\hline age & 28.26 & $(5.34)$ & 28.09 & $(6.31)$ \\
\hline njobs & 1.11 & $(1.38)$ & 0.92 & $(1.09)$ \\
\hline feduc & 0.26 & $(0.43)$ & 0.18 & $(0.38)$ \\
\hline meduc & 0.15 & $(0.36)$ & 0.09 & $(0.28)$ \\
\hline seduc & 0.72 & $(0.44)$ & 0.59 & $(0.49)$ \\
\hline sibli & 3.12 & $(2.18)$ & 3.36 & $(2.23)$ \\
\hline
\end{tabular}

Notes: wage: nominal monthly wage in baths; ten98 = tenure in 1998; exp98 = previous labor market experience in 1998; ojt = dummy equal to 1 if any OJT training occurred in year h; off= dummy equal to 1 if any OFFJT training occurred in year h; frojt = frequency of OJT in year h; froff = frequency of OFFJT in year $h$; promo= dummy equal to 1 if promoted in year $h$; sojt = sum of ojt from 1998 to year $h$; soff = sum of off from 1998 to year $h$; sfrojt = sum of frojt from 1998 to year h; sfroff = sum of froff from 1998 to year h; spromo = sum of promo from 1998 to year $\mathrm{h}$; edyear = years of education; njobs= number of jobs held before current job; feduc= education of the father (1: higher than primary; 0: primary or less); meduc = education of the mother (1: higher than primary; 0 : primary or less); seduc = education of the oldest sibling (from 0 to 3 ); sibli = number of siblings.

Turning to frequencies, we find similar differences by gender and type of training. Males experience more frequently off the job training (froff) and less frequently on the job training (frojt). A similar ranking holds for cumulated frequencies (sfroff and sfrojt respectively). The evidence based on simple averages suggests the presence both of a negative correlation between educational attainment and OJT and of a positive correlation between education and OFFJT.

With reference to family background, we have information on the father's (feduc) and mother's education (meduc), on the education of the oldest sibling (seduc) (next to oldest if the employee is the oldest) and on the number of siblings (sibli). The information on parental background is recoded to 
generate two $(0,1)$ dummies, with 0 referring to primary education or less and 1 referring to higher education. It turns out that male employees, who have higher educational attainment, have also a "better" family background, since both parents and the oldest sibling have higher education and the number of siblings is smaller.

Finally, we notice that males have on average substantially higher wages and a higher incidence of promotion, both in the final year of the sample (promo) and in the entire reference period (spromo). Table 3 shows the means of the same variables separately for production workers, team leaders and foremen, and for technicians and engineers. As expected, the latter group is better educated than the former and receives on average less OJT and more OFFJT. Given the type of job they are likely to be in, engineers are bound to receive more formal OFFJT than shop floor employees.

Table 3. Means and standard deviations of the main variables, by job. 2001.

\begin{tabular}{|c|c|c|c|c|}
\hline \multirow{2}{*}{$\begin{array}{l}\# \text { obs : } \\
-------- \\
\text { wage }\end{array}$} & \multicolumn{2}{|c|}{$\begin{array}{c}1465 \\
\text { production }\end{array}$} & \multicolumn{2}{|c|}{$\begin{array}{c}272 \\
\text { tech+eng }\end{array}$} \\
\hline & 10157 & $(5945)$ & 17755 & $(8851)$ \\
\hline ten 98 & 3.20 & $(3.86)$ & 2.01 & $(2.73)$ \\
\hline $\exp 98$ & 2.35 & $(3.74)$ & 1.58 & $(2.76)$ \\
\hline ojt & 0.64 & $(0.48)$ & 0.54 & $(0.49)$ \\
\hline offjt & 0.61 & $(0.48)$ & 0.68 & $(0.46)$ \\
\hline frojt & 1.13 & $(1.27)$ & 0.96 & $(1.12)$ \\
\hline froff & 1.71 & $(2.63)$ & 1.93 & $(1.67)$ \\
\hline promo & 0.11 & $(0.31)$ & 0.11 & $(0.32)$ \\
\hline sojt & 2.26 & $(1.66)$ & 1.91 & $(2.65)$ \\
\hline soff & 2.31 & $(1.48)$ & 2.40 & $(1.39)$ \\
\hline sfrojt & 4.00 & $(3.94)$ & 3.30 & $(3.75)$ \\
\hline sfroff & 7.09 & $(10.22)$ & 7.66 & $(9.06)$ \\
\hline spromo & 0.34 & $(0.66)$ & 0.55 & $(0.84)$ \\
\hline edyear & 11.02 & $(3.00)$ & 14.44 & $(1.50)$ \\
\hline age & 28.22 & $(6.22)$ & 27.85 & $(4.06)$ \\
\hline njobs & 0.99 & $(1.22)$ & 1.02 & $(1.23)$ \\
\hline feduc & 0.19 & $(0.39)$ & 0.33 & $(0.47)$ \\
\hline meduc & 0.09 & $(0.29)$ & 0.21 & $(0.40)$ \\
\hline seduc & 0.59 & $(0.49)$ & 0.82 & $(0.38)$ \\
\hline sibli & 3.36 & $(2.23)$ & 2.93 & $(2.06)$ \\
\hline
\end{tabular}

Notes: see Table 2. 


\section{The Econometric Specification}

The simple models presented in Section 2 of the paper show the relationship between optimal investment in training and technical complementarity between education and training. While training in these models is a continuous flow variable, our data include both qualitative information on whether training has taken place in a given interval of time and measures of training frequency. We treat the former as an indicator of training incidence. Since the information on whether there has been any training during the reference period (a year) is organized as a $(0,1)$ dummy variable, we use the Probit specification. On the other hand, we consider frequency information as count data, because of the large number of zeros and small values (see Greene [1993]), and use a Poisson specification.

We pool the available data over the period 1999-2001 and estimate the following empirical training models

$$
\begin{aligned}
& \text { ojt }=\Phi\left(\text { edyear, } X, Y, Z, F D, Y D, J D, I D^{*} Y D\right) \\
& \text { off }=\Phi\left(\text { edyear }, X, Y, Z, F D, Y D, J D, I D^{*} Y D\right) \\
& \text { frojt }=P\left(\text { edyear, } X, Y, Z, F D, Y D, J D, I D^{*} Y D\right) \\
& \text { froff }=P\left(\text { edyear, } X, Y, Z, F D, Y D, J D, I D^{*} Y D\right)
\end{aligned}
$$

where $\Phi$ is for the standard Normal and $\mathrm{P}$ for the Poisson distribution, $X$ is a vector of individual variables, which includes tenure and experience in 1998, gender (sex), marital status (marry), household size (hsize), the number of previous jobs held, whether the first job was in production (fjprod), and whether the first job was quitted because of the prospect of better wages (fjquiw), $\mathrm{Z}$ is a vector including lagged training of either type and lagged promotion, and $F D, Y D, J D$ and $I D * Y D$ are vectors of firm, year, job and industry by year dummies. For each specification, we experiment with and without the lagged variables in vector $Z$.

Since training incidence and frequency depend on individual ability, which is usually not observed by the econometrician, we try to capture differences in ability with family background variables. The underlying idea is that unobserved ability can be considered "..as the consequence of the genetic and environmental contribution of the family..." (Willis [1986], p.584). Vector Y therefore includes the father's, the mother's and the oldest sibling education, the number of siblings, whether the employee is the oldest son or daughter and three dummies for the macro-region of birth. These dummies 
are expected to capture differences in school quality, which also influences the development of individual ability, in the three areas outside Greater Bangkok (the omitted area).

Training incidence equations tell us whether variations across individuals in educational attainment affect the probability of training. Whether this probability increases or decreases depends, in equilibrium, on the relative shifts of the marginal benefits and marginal costs schedules. As shown in Figure 1, the marginal benefits schedule shifts upwards if there is technical complementarity between education and training. Technical complementarity is a propriety of the production function and cannot be directly tested unless we observe individual productivity. Since this information is not available, we make the standard assumption of proportionality between productivity and wages and estimate the following Mincerian equation

$$
\begin{aligned}
\ln W=\alpha & + \text { Bedyear }+\gamma \text { sojt }_{-1}+\delta_{\text {soff }_{-1}}+\mu\left(\text { edyear }^{*} \text { sojt }_{-1}\right)+\lambda\left(\text { edyear }^{*} \operatorname{soff}_{-1}\right) \\
& +\theta\left(\text { sojt }_{-1} * \text { soff }_{-1}\right)+\rho\left(\text { sojt }_{-1} * \text { promo }_{-1}\right)+\sigma\left(\text { soff }_{-1} * \text { promo }_{-1}\right)+\varsigma\left(\text { edyear }^{*} \text { ten } 98\right) \\
& +\omega(\text { edyear } * \exp 98)+\psi X+\zeta Y+(F D, Y D, J D, I D * Y D)+\varepsilon
\end{aligned}
$$

where we ignore the time subscript and sojt and soff are the cumulated training events from the start of the reference period (1998) to the selected year ${ }^{6}$. Following the indications of our simple models, we use cumulated events rather than current events (ojt and off) because wages are affected by the stock of human capital accumulated by training, not just by the most recent flow. Cumulated events can proxy accumulated human capital during the window covered by the questionnaire, but do not capture the initial stock of human capital before the start of the observation period. We capture this stock with tenure and labor market experience at the start of the sample, in 1998. While (21) is specified as a function of cumulated training events, we also experiment with cumulated training frequencies (sfrojt and sfroff).

We use lagged rather than current cumulated training to exploit the natural sequence of events in the data: wages in January 2000 are affected by training during 1998 and 1999, not by training in later years. We also add a full set of interactions, between different types of training and education, between education, tenure and experience, between training and lagged cumulated promotion and finally between on the job and off the job training. As in the training incidence equation, we pool the available information (from 1999 to 2001 because of the presence of lags) and use the full set of firm, year, job and

\footnotetext{
${ }^{6}$ For instance, we consider training in 1998 and 1999 for the wage in January 2000 and training in 1998 for the wage in January 1999.
} 
industry by year dummies. Beside the individual controls in $X$, we also include family background variables $(Y)$, again with the purpose of capturing cross section differences in individual unobserved ability.

Assuming that wages are proportional to output per head, technical complementarity requires that

$$
\frac{1}{W} \frac{\partial^{2} W}{\partial T \partial E}=\frac{\partial \ln W}{\partial T \partial E}+\frac{\partial \ln W}{\partial T} \frac{\partial \ln W}{\partial E}
$$

where the second term on the right hand side reflects the fact that the Mincerian equation is nonlinear in education and training. If human capital increases productivity and wages, and training and education contribute positively to the accumulation of human capital, both elements in the second term are positive. It follows that a sufficient (but not necessary) condition for technical complementarity is that $\frac{\partial \ln W}{\partial T \partial E}=\mu+\varsigma+\omega>0$ in the case of OJT and $\frac{\partial \ln W}{\partial T \partial E}=\lambda+\varsigma+\omega>0$ in the case of OFFJT.

\section{The Results}

\section{a) Training Incidence}

We start the presentation of our results from training incidence. For each training type (on the job or off the job) we estimate a Probit model when the dependent variable is the event of training in each year and a Poisson model when the dependent variable is the frequency of training in each year. For each model, we estimate two specifications, one with and one without family background variables.

Consider first OJT (Tables 4 and 5 for training incidence and frequency respectively). We find that individuals with higher education have significantly lower training incidence. This finding remains even when we include lagged training and promotion among the explanatory variables. There is also evidence that individuals with higher previous labor market experience and tenure in the firm have significantly lower training incidence. If we interpret these variables as accumulated training before 1998, this suggests that individuals with a higher initial stock of human capital accumulated in the labor market need less OJT. Lagged OJT influences strongly current OJT, which points to persistence. On the other hand, having received OFFJT in the previous period reduces the likelihood of currently receiving OJT. Finally, we find that the inclusion of family background variables affect only marginally the coefficient associated to years of education. 
Table 4. OJT Training Incidence. All Workers. Dependent variable: ojt

\begin{tabular}{|c|c|c|c|c|}
\hline \# obs : & 5202 & 4899 & 5202 & 4899 \\
\hline Depvar: & ojt & ojt & ojt & ojt \\
\hline ten 98 & $\begin{array}{l}-0.0088 * \\
(0.0063)\end{array}$ & $\begin{array}{l}-0.0117 * \\
(0.0066)\end{array}$ & $\begin{array}{l}-0.0327 * \\
(0.0078)\end{array}$ & $\begin{array}{l}-0.0325 * \\
(0.0083)\end{array}$ \\
\hline exp98 & $\begin{array}{l}-0.0155 \sim \\
(0.0066)\end{array}$ & $\begin{array}{l}-0.0156 \sim \\
(0.0068)\end{array}$ & $\begin{array}{l}-0.0195 \sim \\
(0.0079)\end{array}$ & $\begin{array}{l}-0.0195 \sim \\
(0.0081)\end{array}$ \\
\hline marry & $\begin{array}{c}0.0048 * \\
(0.0204)\end{array}$ & $\begin{array}{c}0.0143 * \\
(0.0211)\end{array}$ & $\begin{array}{c}-0.0411 \\
(0.0249)\end{array}$ & $\begin{array}{c}-0.0367 \\
(0.0258)\end{array}$ \\
\hline sex & $\begin{array}{l}-0.2344^{\star} \\
(0.0515)\end{array}$ & $\begin{array}{l}-0.2486 \star \\
(0.0539)\end{array}$ & $\begin{array}{l}-0.1690 \star \\
(0.0611)\end{array}$ & $\begin{array}{l}-0.1862 * \\
(0.0636)\end{array}$ \\
\hline hsize & $\begin{array}{l}-0.0414 \text { * } \\
(0.0090)\end{array}$ & $\begin{array}{l}-0.0454 \text { * } \\
(0.0096)\end{array}$ & $\begin{array}{l}-0.0130 \sim \\
(0.0116)\end{array}$ & $\begin{array}{l}-0.0145 \sim \\
(0.0124)\end{array}$ \\
\hline edyear & $\begin{array}{l}-0.0578 * \\
(0.0089)\end{array}$ & $\begin{array}{l}-0.0572 \star \\
(0.0095)\end{array}$ & $\begin{array}{l}-0.0278 * \\
(0.0104)\end{array}$ & $\begin{array}{l}-0.0284 \sim \\
(0.0112)\end{array}$ \\
\hline f jprod & $\begin{array}{r}0.0295 \\
(0.0458)\end{array}$ & $\begin{array}{c}0.0224 \\
(0.0470)\end{array}$ & $\begin{array}{r}0.0248 \\
(0.0546)\end{array}$ & $\begin{array}{r}0.0235 \\
(0.0561)\end{array}$ \\
\hline njobs & $\begin{array}{l}-0.0082 \sim \\
(0.0197)\end{array}$ & $\begin{array}{c}-0.0093 \\
(0.0206)\end{array}$ & $\begin{array}{r}0.0097 \\
(0.0225)\end{array}$ & $\begin{array}{r}0.0058 \\
(0.0231)\end{array}$ \\
\hline fjquiw & $\begin{array}{c}0.130 * \\
(0.0487)\end{array}$ & $\begin{array}{c}0.1412 * \\
(0.0506)\end{array}$ & $\begin{array}{c}0.0542 \sim \\
(0.0581)\end{array}$ & $\begin{array}{r}0.0567 \\
(0.0602)\end{array}$ \\
\hline feduc & & $\begin{array}{l}-0.1366 \sim \\
(0.0542)\end{array}$ & & $\begin{array}{c}-0.1203 \\
(0.0682)\end{array}$ \\
\hline meduc & & $\begin{array}{c}-0.0823 \\
(0.0696)\end{array}$ & & $\begin{array}{c}0.0092 \\
(0.0856)\end{array}$ \\
\hline seduc & & $\begin{array}{c}0.0752 \sim \\
(0.0333)\end{array}$ & & $\begin{array}{r}0.0604 \\
(0.0407)\end{array}$ \\
\hline oldest & & $\begin{array}{c}-0.0349 \\
(0.0460)\end{array}$ & & $\begin{array}{l}-0.0548 \sim \\
(0.0567)\end{array}$ \\
\hline sibli & & $\begin{array}{r}0.0003 \\
(0.0103)\end{array}$ & & $\begin{array}{c}-0.0007 \\
(0.0130)\end{array}$ \\
\hline ojt $(-1)$ & & & $\begin{array}{c}2.1689 * \\
(0.0522)\end{array}$ & $\begin{array}{c}2.1927 * \\
(0.0548)\end{array}$ \\
\hline promo $(-1)$ & & & $\begin{array}{c}-0.1138 \\
(0.0841)\end{array}$ & $\begin{array}{c}-0.1368 \\
(0.0852)\end{array}$ \\
\hline $\operatorname{off}(-1)$ & & & $\begin{array}{c}-0.2216^{\star} \\
(0.0562)\end{array}$ & $\begin{array}{c}-0.2540 * \\
(0.0589)\end{array}$ \\
\hline Reg & Yes & Yes & Yes & Yes \\
\hline Firm & Yes & Yes & Yes & Yes \\
\hline Job & Yes & Yes & Yes & Yes \\
\hline Year & Yes & Yes & Yes & Yes \\
\hline YI & Yes & Yes & Yes & Yes \\
\hline
\end{tabular}

Notes: see Table 2. Oldest: whether the employee is the oldest son or daughter; fjprod: whether first job was in production; fjquiw: whether first job was quitted because of better wage prospects; reg = region of birth dummies; firm: firm dummies; Job: job dummies; Year: year dummies; YI: year by industry dummies; sex: gender dummy (1:male); marry: marital status dummy; hsize: household size; ten98: tenure in 1998; exp98: labor market experience in 1998. 
Conditional on education and experience, training is less frequent among female employees and among individuals who belong to larger households. Since household size is larger on average among female workers with poorer family background, this variable could be capturing the joint negative effect of gender and family background on training incidence. A possible interpretation of this result is that employers statistically discriminate against female employees.

Table 5. OJT Training Incidence. All Workers. Dependent variable: frojt

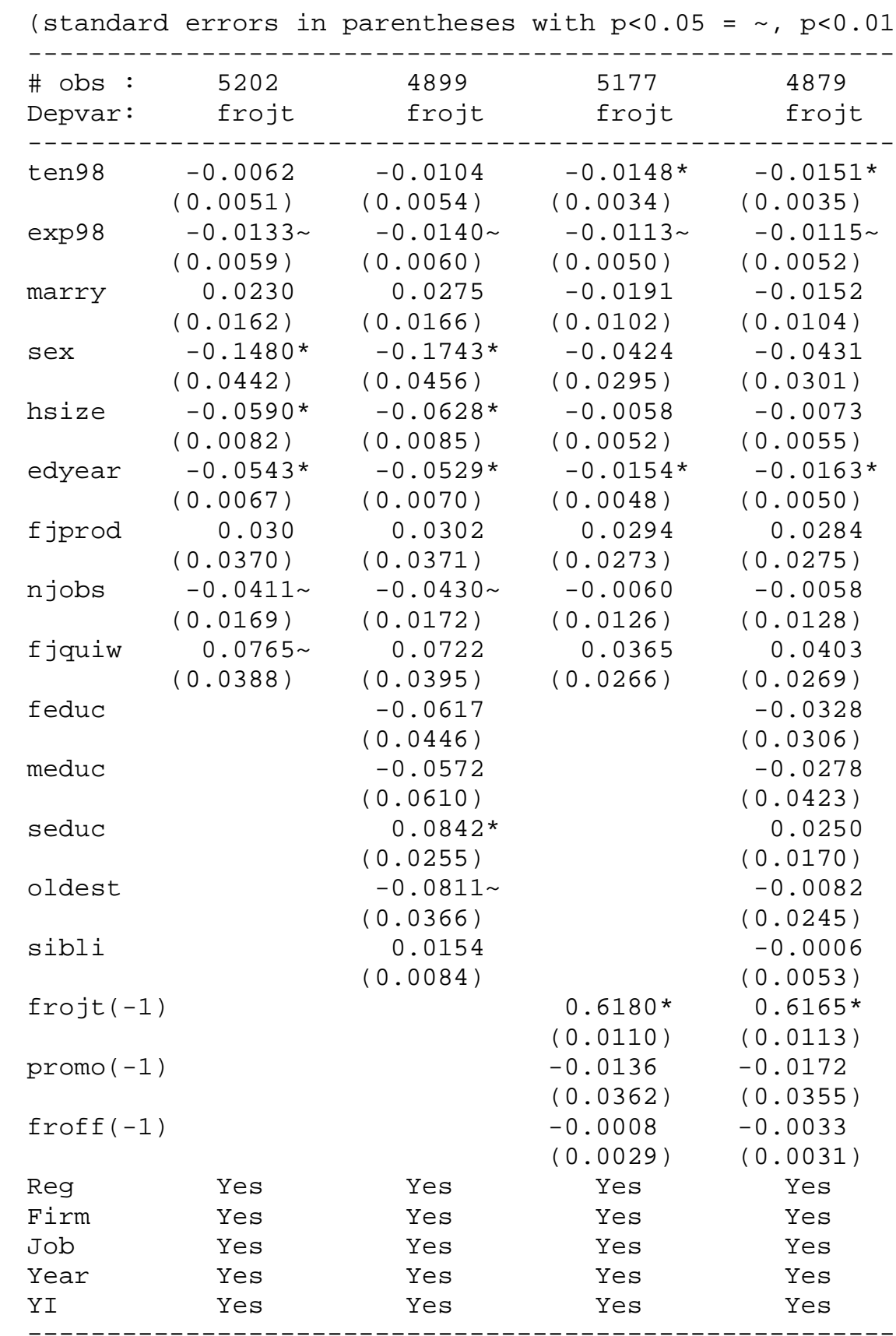

Note: see Table 4 . 
The uncovered negative relation between educational attainment and OJT could simply be driven by the fact that we are including different jobs in the same regression. If engineers have higher education and lower OJT than production workers, this between - jobs variation could explain our results. To check this, we run the same regressions by retaining only production workers. Results in Table 6 below $^{7}$ show that the relation between education and OJT remains negative and significant.

Table 6. OJT Training Incidence. Production workers only. Dependent variable: ojt

\begin{tabular}{|c|c|c|c|c|}
\hline $\begin{array}{l}\text { \# obs : } \\
\text { Depvar: }\end{array}$ & $\begin{array}{r}3420 \\
\text { ojt }\end{array}$ & $\begin{array}{r}3228 \\
\text { ojt }\end{array}$ & $\begin{array}{r}3420 \\
\text { ojt }\end{array}$ & $\begin{array}{c}3228 \\
\text { ojt }\end{array}$ \\
\hline ten 98 & $\begin{array}{r}-0.0097 \\
(0.0081)\end{array}$ & $\begin{array}{c}-0.0165 \\
(0.0085)\end{array}$ & $\begin{array}{l}-0.0415 * \\
(0.0098)\end{array}$ & $\begin{array}{l}-0.0448 * \\
(0.0103)\end{array}$ \\
\hline $\exp 98$ & $\begin{array}{c}-0.0128 \\
(0.0082)\end{array}$ & $\begin{array}{l}-0.0123 \\
(0.0084)\end{array}$ & $\begin{array}{l}-0.0205 \sim \\
(0.0095)\end{array}$ & $\begin{array}{l}-0.0197 \sim \\
(0.0097)\end{array}$ \\
\hline marry & $\begin{array}{r}0.0271 \\
(0.0250)\end{array}$ & $\begin{array}{r}0.0503 \\
(0.0259)\end{array}$ & $\begin{array}{c}-0.0324 \\
(0.0296)\end{array}$ & $\begin{array}{c}-0.0231 \\
(0.0307)\end{array}$ \\
\hline sex & $\begin{array}{l}-0.1723 \sim \\
(0.0674)\end{array}$ & $\begin{array}{l}-0.1880 * \\
(0.0713)\end{array}$ & $\begin{array}{l}-0.1568 \sim \\
(0.0772)\end{array}$ & $\begin{array}{l}-0.1811 \sim \\
(0.0818)\end{array}$ \\
\hline hsize & $\begin{array}{l}-0.0477 \star \\
(0.0111)\end{array}$ & $\begin{array}{l}-0.0559 \star \\
(0.0119)\end{array}$ & $\begin{array}{r}-0.0117 \\
(0.0138)\end{array}$ & $\begin{array}{c}-0.0165 \\
(0.0149)\end{array}$ \\
\hline edyear & $\begin{array}{l}-0.0675^{\star} \\
(0.0108)\end{array}$ & $\begin{array}{l}-0.0711 \star \\
(0.0115)\end{array}$ & $\begin{array}{l}-0.0333^{*} \\
(0.0123)\end{array}$ & $\begin{array}{l}-0.0359 * \\
(0.0133)\end{array}$ \\
\hline f jprod & $\begin{array}{r}0.0718 \\
(0.0550)\end{array}$ & $\begin{array}{r}0.0424 \\
(0.0563)\end{array}$ & $\begin{array}{c}0.0584 \\
(0.0651)\end{array}$ & $\begin{array}{r}0.0470 \\
(0.0670)\end{array}$ \\
\hline njobs & $\begin{array}{c}-0.0168 \\
(0.0254)\end{array}$ & $\begin{array}{c}-0.0289 \\
(0.0261)\end{array}$ & $\begin{array}{c}-0.0019 \\
(0.0290)\end{array}$ & $\begin{array}{c}-0.0141 \\
(0.0298)\end{array}$ \\
\hline fjquiw & $\begin{array}{r}0.0495 \\
(0.0593)\end{array}$ & $\begin{array}{r}0.0699 \\
(0.0614)\end{array}$ & $\begin{array}{r}0.0428 \\
(0.0688)\end{array}$ & $\begin{array}{r}0.0570 \\
(0.0708)\end{array}$ \\
\hline feduc & & $\begin{array}{l}-0.1776 \star \\
(0.0681)\end{array}$ & & $\begin{array}{r}-0.1517 \\
(0.0856)\end{array}$ \\
\hline meduc & & $\begin{array}{c}-0.0171 \\
(0.0932)\end{array}$ & & $\begin{array}{c}0.1034 \\
(0.1110)\end{array}$ \\
\hline seduc & & $\begin{array}{c}0.0911 \sim \\
(0.0427)\end{array}$ & & $\begin{array}{r}0.0801 \\
(0.0511)\end{array}$ \\
\hline oldest & & $\begin{array}{r}0.0095 \\
(0.0571)\end{array}$ & & $\begin{array}{l}-0.0068 \\
(0.0688)\end{array}$ \\
\hline sibli & & $\begin{array}{r}0.0102 \\
(0.0129) \\
(0.0774)\end{array}$ & & $\begin{array}{c}0.0081 \\
(0.0158) \\
(0.0945)\end{array}$ \\
\hline ojt $(-1)$ & & & $\begin{array}{c}2.1009 * \\
(0.0649)\end{array}$ & $\begin{array}{c}2.1170 * \\
(0.0680)\end{array}$ \\
\hline promo $(-1)$ & & & $\begin{array}{l}-0.1685 \\
(0.1228)\end{array}$ & $\begin{array}{l}-0.1863 \\
(0.1244)\end{array}$ \\
\hline off $(-1)$ & & & $\begin{array}{l}-0.2421^{\star} \\
(0.0664)\end{array}$ & $\begin{array}{r}-0.2779 * \\
(0.0695)\end{array}$ \\
\hline Reg & Yes & Yes & Yes & Yes \\
\hline Firm & Yes & Yes & Yes & Yes \\
\hline Job & Yes & Yes & Yes & Yes \\
\hline Year & Yes & Yes & Yes & Yes \\
\hline YI & Yes & Yes & Yes & Yes \\
\hline
\end{tabular}

Note: see Table 4.

\footnotetext{
${ }^{7}$ Results (available upon request) do not change when we use training frequency.
} 
Turning to OFFJT (Tables 7 and 8 for training incidence and frequency respectively), we find that the relationship between education and training incidence is positive but not significantly different from zero. In contrast to the results for OJT, there is evidence that the incidence of OFFJT increases with tenure at the start of the sample period.

Table 7. OJT Training Incidence. All Workers. Dependent variable: offjt

\begin{tabular}{|c|c|c|c|c|}
\hline $\begin{array}{l}\text { \# obs : } \\
\text { Depvar: }\end{array}$ & $\begin{array}{r}5202 \\
\text { off }\end{array}$ & $\begin{array}{r}4899 \\
\text { off }\end{array}$ & $\begin{array}{r}5202 \\
\text { off }\end{array}$ & $\begin{array}{r}4899 \\
\text { off }\end{array}$ \\
\hline \multirow[t]{2}{*}{ ten98 } & $0.0444 *$ & $0.0407 *$ & 0.0132 & 0.0126 \\
\hline & $(0.0072)$ & $(0.0075)$ & $(0.0075)$ & $(0.0079)$ \\
\hline \multirow[t]{2}{*}{$\exp 98$} & 0.0128 & 0.0127 & 0.0065 & 0.0066 \\
\hline & $(0.0071)$ & $(0.0073)$ & $(0.0077)$ & $(0.0079)$ \\
\hline \multirow[t]{2}{*}{ marry } & 0.0033 & 0.0010 & -0.0354 & -0.0417 \\
\hline & $(0.0209)$ & $(0.0216)$ & $(0.0228)$ & $(0.0236)$ \\
\hline \multirow[t]{2}{*}{ sex } & -0.0647 & -0.0786 & -0.0158 & -0.0222 \\
\hline & $(0.0536)$ & $(0.0559)$ & $(0.0573)$ & $(0.060)$ \\
\hline \multirow[t]{2}{*}{ hsize } & 0.0021 & 0.0045 & 0.0097 & 0.0120 \\
\hline & $(0.0091)$ & $(0.0097)$ & $(0.010)$ & $(0.0106)$ \\
\hline \multirow{2}{*}{ edyear } & 0.0051 & 0.0046 & 0.0110 & 0.0134 \\
\hline & $(0.0091)$ & $(0.0097)$ & $(0.0097)$ & $(0.0104)$ \\
\hline \multirow[t]{2}{*}{ f jprod } & 0.0215 & 0.0075 & -0.0026 & -0.0033 \\
\hline & $(0.0470)$ & $(0.0481)$ & $(0.0506)$ & $(0.0518)$ \\
\hline \multirow[t]{2}{*}{ njobs } & -0.0195 & -0.0186 & -0.0134 & -0.0136 \\
\hline & $(0.0199)$ & $(0.0205)$ & $(0.0217)$ & $(0.0222)$ \\
\hline \multirow[t]{2}{*}{ fjquiw } & $0.1693 *$ & 0.1644 * & 0.0997 & 0.0901 \\
\hline & $(0.0495)$ & $(0.0510)$ & $(0.0530)$ & $(0.0546)$ \\
\hline \multirow{2}{*}{ feduc } & & -0.0891 & & -0.0170 \\
\hline & & $(0.0558)$ & & $(0.0591)$ \\
\hline \multirow[t]{2}{*}{ meduc } & & 0.1419 & & 0.1035 \\
\hline & & $(0.0750)$ & & $(0.0792)$ \\
\hline \multirow[t]{2}{*}{ seduc } & & -0.0282 & & -0.0430 \\
\hline & & $(0.0342)$ & & $(0.0366)$ \\
\hline \multirow[t]{2}{*}{ oldest } & & $-0.1151 \sim$ & & -0.0812 \\
\hline & & $(0.0468)$ & & $(0.0504)$ \\
\hline \multirow[t]{2}{*}{ sibli } & & 0.0020 & & -0.0006 \\
\hline & & $(0.0107)$ & & $(0.0115)$ \\
\hline \multirow[t]{2}{*}{ ojt $(-1)$} & & & $0.2394 *$ & $0.2363 *$ \\
\hline & & & $(0.0449)$ & $(0.0467)$ \\
\hline \multirow[t]{2}{*}{ promo $(-1)$} & & & -0.0786 & -0.0789 \\
\hline & & & $(0.0742)$ & $(0.0766)$ \\
\hline \multirow[t]{2}{*}{ off $(-1)$} & & & $1.2375 \star$ & $1.2347 *$ \\
\hline & & & $(0.0458)$ & $(0.0473)$ \\
\hline Reg & Yes & Yes & Yes & Yes \\
\hline Firm & Yes & Yes & Yes & Yes \\
\hline Job & Yes & Yes & Yes & Yes \\
\hline Year & Yes & Yes & Yes & Yes \\
\hline YI & Yes & Yes & Yes & Yes \\
\hline
\end{tabular}

$=============$
Notes: see Table 4 . 
While we find that having had OJT in the previous period improves OFFJT incidence in the current period, there is no significant evidence that female employees receive less OFFJT than their male colleagues.

Table 8. OJT Training Incidence. All Workers. Dependent variable: froff

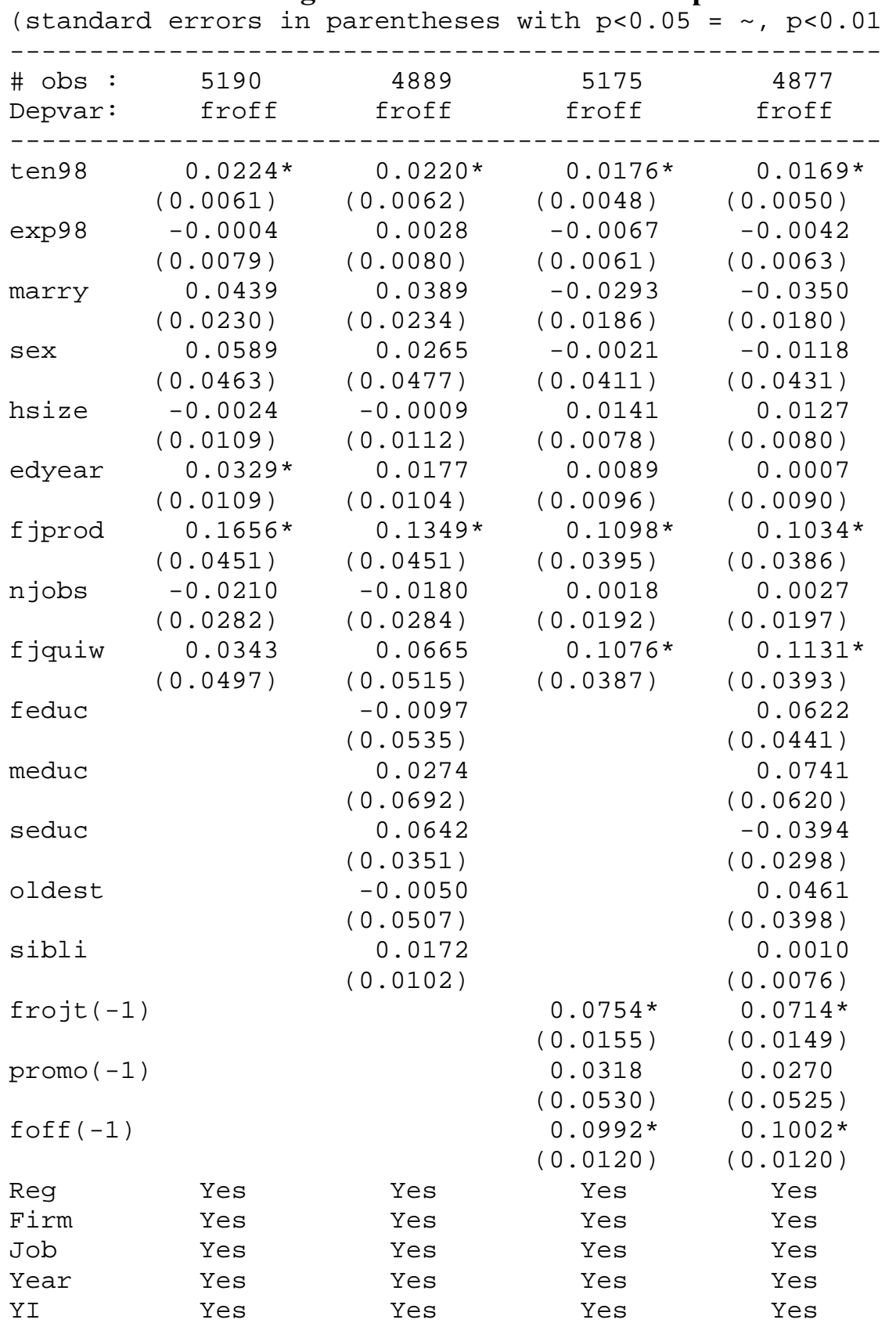

Notes: see Table 4 . 
The finding that the incidence and frequency of training depends both on education and on previous training (of either type) implies that, in the long run, higher education affects each type of training both directly and indirectly, by influencing the other type as well. We have checked in our data whether the overall direction of the relationship between education and training changes in the long run compared to the short run, when previous training is given, but found no instance of such an occurrence.

\section{b) Mincerian wage regressions.}

Since the standard Mincerian earnings function does not include training and occupational dummies, we start by estimating a simplified version of [21], which excludes cumulated training, interaction terms and job dummies. In line with the traditional specification, we retain tenure and experience net of tenure and investigate whether the estimated returns to education vary significantly with the inclusion of family background controls. Table 9 presents our findings for the full sample and two sub-samples, one for production workers (inclusive of team leaders and supervisors) and one for technicians and engineers.

It turns out that the inclusion of family background variables reduces the estimated returns to education by close to $9 \%$ in the full sample and in the sub - sample of production workers and by close to $5 \%$ in the sub - sample of technicians and engineers. Since the estimated returns to tenure and previous labor market experience also fall, the returns to human capital are significantly affected in the expected direction by the addition of information on parental education and region of birth. We find that the marginal returns to education in the full sample are equal to $5.3 \%$ per year, much less than $10.4 \%$, the value reported for Thailand by Psacharopoulos [1994]. Only technicians and engineers in our sample get close to this number, with a marginal return equal to $15 \%$.

Next, we estimate equation [21] by adding training variables, job dummies and the relevant interactions. Table 10 shows the results of four regressions. While in the former two columns we measure training as cumulated events over the relevant interval, in the latter two columns we measure it as cumulated frequencies. For each measure of training, we estimate a wage regression with and without interactions between training, education and promotion. Each specification includes both individual characteristics and family background variables.

We find that monthly earnings are higher for married males with higher tenure and previous experience who have quit their first job because of better wage prospects and who have been promoted in the interval period. Focusing on columns (1) and (3) of the table, our evidence also shows that, 
conditional on education, monthly earnings are positively affected by training. These effects are bigger for OFFJT when we measure it as the sum of events in the sample period and bigger for OJT when we measure it as the frequency of training events.

Table 9. Mincerian Wage Regressions without Training and Occupational Dummies.

\begin{tabular}{|c|c|c|c|c|c|c|}
\hline $\begin{array}{l}\# \text { obs : } \\
\text { Depvar: }\end{array}$ & $\begin{array}{l}4671 \\
\text { wage }\end{array}$ & $\begin{array}{l}4419 \\
\text { wage }\end{array}$ & $\begin{array}{l}3953 \\
\text { wage }\end{array}$ & $\begin{array}{l}3747 \\
\text { wage }\end{array}$ & $\begin{array}{r}718 \\
\text { wage }\end{array}$ & $\begin{array}{r}672 \\
\text { wage }\end{array}$ \\
\hline ten 98 & $\begin{array}{c}0.0418 * \\
(0.0018)\end{array}$ & $\begin{array}{c}0.0385 * \\
(0.0019)\end{array}$ & $\begin{array}{c}0.0402 * \\
(0.0019)\end{array}$ & $\begin{array}{c}0.0372 * \\
(0.0019)\end{array}$ & $\begin{array}{c}0.0731 * \\
(0.0059)\end{array}$ & $\begin{array}{c}0.0692 * \\
(0.0058)\end{array}$ \\
\hline $\exp 98$ & $\begin{array}{c}0.0151 * \\
(0.0025)\end{array}$ & $\begin{array}{c}0.0134 * \\
(0.0025)\end{array}$ & $\begin{array}{c}0.0141 * \\
(0.0025)\end{array}$ & $\begin{array}{c}0.0130 * \\
(0.0025)\end{array}$ & $\begin{array}{c}0.0449 * \\
(0.0067)\end{array}$ & $\begin{array}{l}0.040 * \\
(0.0073)\end{array}$ \\
\hline fjprod & $\begin{array}{c}-0.0219 \\
(0.0146)\end{array}$ & $\begin{array}{c}-0.0159 \\
(0.0146)\end{array}$ & $\begin{array}{c}-0.0210 \\
(0.0154)\end{array}$ & $\begin{array}{c}-0.0144 \\
(0.0152)\end{array}$ & $\begin{array}{r}0.0194 \\
(0.0307)\end{array}$ & $\begin{array}{r}0.0386 \\
(0.0317)\end{array}$ \\
\hline njobs & $\begin{array}{c}-0.0069 \\
(0.0066)\end{array}$ & $\begin{array}{c}-0.0090 \\
(0.0066)\end{array}$ & $\begin{array}{c}-0.0122 \\
(0.0069)\end{array}$ & $\begin{array}{l}-0.0137 \sim \\
(0.0069)\end{array}$ & $\begin{array}{r}0.0111 \\
(0.0117)\end{array}$ & $\begin{array}{r}0.0121 \\
(0.0118)\end{array}$ \\
\hline fjquiw & $\begin{array}{c}0.0313 \sim \\
(0.0153)\end{array}$ & $\begin{array}{c}0.0421 * \\
(0.0154)\end{array}$ & $\begin{array}{c}0.0515 * \\
(0.0166)\end{array}$ & $\begin{array}{c}0.0547 * \\
(0.0166)\end{array}$ & $\begin{array}{l}-0.0875 * \\
(0.0322)\end{array}$ & $\begin{array}{l}-0.0786 \sim \\
(0.0329)\end{array}$ \\
\hline marry & $\begin{array}{c}0.0225^{\star} \\
(0.0063)\end{array}$ & $\begin{array}{c}0.0249 * \\
(0.0064)\end{array}$ & $\begin{array}{c}0.0231 * \\
(0.0067)\end{array}$ & $\begin{array}{c}0.0224 * \\
(0.0068)\end{array}$ & $\begin{array}{r}0.0026 \\
(0.0139)\end{array}$ & $\begin{array}{r}0.0123 \\
(0.0144)\end{array}$ \\
\hline sex & $\begin{array}{c}0.2466^{\star} \\
(0.0152)\end{array}$ & $\begin{array}{c}0.2243 * \\
(0.0152)\end{array}$ & $\begin{array}{c}0.1951 * \\
(0.0181)\end{array}$ & $\begin{array}{c}0.1756^{\star} \\
(0.0180)\end{array}$ & $\begin{array}{c}-0.0102 \\
(0.070)\end{array}$ & $\begin{array}{c}-0.0360 \\
(0.0776)\end{array}$ \\
\hline hsize & $\begin{array}{c}-0.0040 \\
(0.0028)\end{array}$ & $\begin{array}{l}-0.0079 * \\
(0.0029)\end{array}$ & $\begin{array}{r}0.0010 \\
(0.0029)\end{array}$ & $\begin{array}{c}-0.0027 \\
(0.0030)\end{array}$ & $\begin{array}{l}-0.0162 \sim \\
(0.0076)\end{array}$ & $\begin{array}{l}-0.0194 \sim \\
(0.0082)\end{array}$ \\
\hline edyear & $\begin{array}{c}0.0589 * \\
(0.0028)\end{array}$ & $\begin{array}{c}0.0533 * \\
(0.0030)\end{array}$ & $\begin{array}{c}0.0477 * \\
(0.0029)\end{array}$ & $\begin{array}{c}0.0434 * \\
(0.0030)\end{array}$ & $\begin{array}{c}0.1643 * \\
(0.0122)\end{array}$ & $\begin{array}{c}0.1552 * \\
(0.0129)\end{array}$ \\
\hline re 1 & & $\begin{array}{l}-0.0644 * \\
(0.0167)\end{array}$ & & $\begin{array}{c}-0.060 * \\
(0.0180)\end{array}$ & & $\begin{array}{r}0.0000 \\
(0.0379)\end{array}$ \\
\hline re2 & & $\begin{array}{c}-0.0345 \\
(0.0196)\end{array}$ & & $\begin{array}{c}-0.0346 \\
(0.0210)\end{array}$ & & $\begin{array}{c}-0.0684 \\
(0.0413)\end{array}$ \\
\hline re 4 & & $\begin{array}{l}-0.0459 \sim \\
(0.0189)\end{array}$ & & $\begin{array}{l}-0.0672 * \\
(0.0207)\end{array}$ & & $\begin{array}{r}0.0059 \\
(0.0372)\end{array}$ \\
\hline feduc & & $\begin{array}{c}-0.0045 \\
(0.0183)\end{array}$ & & $\begin{array}{c}-0.0093 \\
(0.0198)\end{array}$ & & $\begin{array}{c}-0.0722 \\
(0.0422)\end{array}$ \\
\hline meduc & & $\begin{array}{c}0.1233 * \\
(0.0238)\end{array}$ & & $\begin{array}{c}0.1166 * \\
(0.0267)\end{array}$ & & $\begin{array}{r}0.0606 \\
(0.0494)\end{array}$ \\
\hline seduc & & $\begin{array}{c}0.0226 \sim \\
(0.0099)\end{array}$ & & $\begin{array}{r}0.0199 \\
(0.0108)\end{array}$ & & $\begin{array}{c}0.0084 \\
(0.0214)\end{array}$ \\
\hline oldest & & $\begin{array}{c}0.0034 \\
(0.0143)\end{array}$ & & $\begin{array}{c}-0.0006 \\
(0.0151)\end{array}$ & & $\begin{array}{r}0.0151 \\
(0.0340)\end{array}$ \\
\hline sibli & & $\begin{array}{c}0.0140 * \\
(0.0031)\end{array}$ & & $\begin{array}{c}0.0134 * \\
(0.0034)\end{array}$ & & $\begin{array}{r}0.0078 \\
(0.0077)\end{array}$ \\
\hline Firm & Yes & Yes & Yes & Yes & Yes & Yes \\
\hline Year & Yes & Yes & Yes & Yes & Yes & Yes \\
\hline YI & Yes & Yes & Yes & Yes & Yes & Yes \\
\hline$R-s q$ & 0.443 & 0.449 & 0.388 & 0.398 & 0.584 & 0.588 \\
\hline
\end{tabular}

Note: see Table 4 
When we consider the interaction terms between training and education, we find that the coefficients associated to the interaction between education and training, tenure and labor market experience are positive, albeit not always significantly different from zero. We have also checked whether log wages are increasing in training and education by evaluating the partial derivatives at the sample means of the relevant variables and found that in all circumstances this regularity condition was met. Therefore, both the sufficient conditions and the overall conditions for technical complementarity hold in our data.

Table 10. Mincerian Wage Regressions with Training and Occupational Dummies.

\begin{tabular}{|c|c|c|c|c|}
\hline \# obs : & 4419 & 4419 & 4419 & 4419 \\
\hline Depvar: & wage & wage & wage & wage \\
\hline ten98 & $\begin{array}{l}0.0296 * \\
(0.0019)\end{array}$ & $\begin{array}{l}0.0198 * \\
(0.0064)\end{array}$ & $\begin{array}{l}0.0303 * \\
(0.0019)\end{array}$ & $\begin{array}{l}0.0198 * \\
(0.0064)\end{array}$ \\
\hline $\exp 98$ & $\begin{array}{l}0.0118 * \\
(0.0024)\end{array}$ & $\begin{array}{l}0.0089 \\
(0.0053)\end{array}$ & $\begin{array}{l}0.0121^{\star} \\
(0.0024)\end{array}$ & $\begin{array}{l}0.0089 \\
(0.0053)\end{array}$ \\
\hline f jprod & $\begin{array}{l}-0.0104 \\
(0.0135)\end{array}$ & $\begin{array}{l}-0.0097 \\
(0.0134)\end{array}$ & $\begin{array}{c}-0.0109 \\
(0.0135)\end{array}$ & $\begin{array}{c}-0.0099 \\
(0.0134)\end{array}$ \\
\hline njobs & $\begin{array}{l}-0.0102 \\
(0.0057)\end{array}$ & $\begin{array}{c}-0.0109 \\
(0.0060)\end{array}$ & $\begin{array}{c}-0.0101 \\
(0.0057)\end{array}$ & $\begin{array}{c}-0.0105 \\
(0.0059)\end{array}$ \\
\hline fjquiw & $\begin{array}{c}0.0483^{*} \\
(0.0145)\end{array}$ & $\begin{array}{c}0.0461 * \\
(0.0146)\end{array}$ & $\begin{array}{c}0.0508 * \\
(0.0146)\end{array}$ & $\begin{array}{c}0.0486 * \\
(0.0146)\end{array}$ \\
\hline marry & $\begin{array}{c}0.0205^{\star} \\
(0.0060)\end{array}$ & $\begin{array}{c}0.0183 * \\
(0.0061)\end{array}$ & $\begin{array}{c}0.0206 * \\
(0.0060)\end{array}$ & $\begin{array}{c}0.0176 * \\
(0.0061)\end{array}$ \\
\hline sex & $\begin{array}{c}0.1292 * \\
(0.0158)\end{array}$ & $\begin{array}{c}0.1260 * \\
(0.0159)\end{array}$ & $\begin{array}{c}0.1278 * \\
(0.0159)\end{array}$ & $\begin{array}{c}0.1231 * \\
(0.0158)\end{array}$ \\
\hline hsize & $\begin{array}{l}-0.0058 \sim \\
(0.0028)\end{array}$ & $\begin{array}{r}-0.0056 \sim \\
(0.0028)\end{array}$ & $\begin{array}{r}-0.0056 \sim \\
(0.0028)\end{array}$ & $\begin{array}{c}-0.0050 \\
(0.0028)\end{array}$ \\
\hline edyear & $\begin{array}{c}0.0336^{*} \\
(0.0030)\end{array}$ & $\begin{array}{c}0.0219 * \\
(0.0045)\end{array}$ & $\begin{array}{c}0.0336^{\star} \\
(0.0030)\end{array}$ & $\begin{array}{c}0.0232 * \\
(0.0042)\end{array}$ \\
\hline spromo $(-1)$ & $\begin{array}{c}0.0523 * \\
(0.0108)\end{array}$ & $\begin{array}{c}0.0624 \text { * } \\
(0.0223)\end{array}$ & $\begin{array}{c}0.0546^{\star} \\
(0.0109)\end{array}$ & $\begin{array}{c}0.0789 * \\
(0.0180)\end{array}$ \\
\hline sojt $(-1)$ & $\begin{array}{c}0.0094 \\
(0.0057)\end{array}$ & $\begin{array}{c}-0.0044 \\
(0.0225)\end{array}$ & & \\
\hline $\operatorname{soff}(-1)$ & $\begin{array}{c}0.0230 * \\
(0.0062)\end{array}$ & $\begin{array}{c}-0.0217 \\
(0.0243)\end{array}$ & & \\
\hline sfrojt $(-1)$ & & & $\begin{array}{c}0.0046 \sim \\
(0.0023)\end{array}$ & $\begin{array}{c}-0.0061 \\
(0.0086)\end{array}$ \\
\hline $\operatorname{sfroff}(-1)$ & & & $\begin{array}{r}0.0023 \sim \\
(0.0010)\end{array}$ & $\begin{array}{c}-0.0088 \sim \\
(0.0044)\end{array}$ \\
\hline esojt $(-1)$ & & $\begin{array}{c}0.0021 \\
(0.0019)\end{array}$ & & \\
\hline $\operatorname{esoff}(-1)$ & & $\begin{array}{c}0.0046 \sim \\
(0.0020)\end{array}$ & & \\
\hline edten 98 & & $\begin{array}{c}0.0009 \\
(0.0006)\end{array}$ & & $\begin{array}{c}0.0010 \\
(0.0006)\end{array}$ \\
\hline edexp98 & & $\begin{array}{c}0.0003 \\
(0.0005)\end{array}$ & & $\begin{array}{c}0.0003 \\
(0.0005)\end{array}$ \\
\hline trint & & $\begin{array}{c}-0.0059 \\
(0.0042)\end{array}$ & & \\
\hline
\end{tabular}




\begin{tabular}{|c|c|c|c|c|}
\hline ojtpro & & $\begin{array}{c}-0.0035 \\
(0.0084)\end{array}$ & & \\
\hline offpro & & $\begin{array}{c}-0.0059 \\
(0.0094)\end{array}$ & & \\
\hline esfrojt & & & & $\begin{array}{c}0.0012 \\
(0.0007)\end{array}$ \\
\hline esfroff & & & & $\begin{array}{c}0.0011^{*} \\
(0.0003)\end{array}$ \\
\hline trintf & & & & $\begin{array}{l}-0.0002 \\
(0.0002)\end{array}$ \\
\hline frojtpr & & & & $\begin{array}{l}-0.0022 \\
(0.0027)\end{array}$ \\
\hline froffpr & & & & $\begin{array}{c}-0.0028 \sim \\
(0.0012)\end{array}$ \\
\hline re1 & $\begin{array}{c}-0.0487 * \\
(0.0156)\end{array}$ & $\begin{array}{c}-0.0506 * \\
(0.0157)\end{array}$ & $\begin{array}{c}-0.0499 * \\
(0.0156)\end{array}$ & $\begin{array}{c}-0.0538 * \\
(0.0156)\end{array}$ \\
\hline re2 & $\begin{array}{c}-0.0254 \\
(0.0183)\end{array}$ & $\begin{array}{c}-0.0271 \\
(0.0183)\end{array}$ & $\begin{array}{c}-0.0261 \\
(0.0183)\end{array}$ & $\begin{array}{c}-0.0282 \\
(0.0183)\end{array}$ \\
\hline re 4 & $\begin{array}{c}-0.0662 * \\
(0.0173)\end{array}$ & $\begin{array}{c}-0.0656^{\star} \\
(0.0173)\end{array}$ & $\begin{array}{c}-0.0665 * \\
(0.0173)\end{array}$ & $\begin{array}{c}-0.0664 \text { * } \\
(0.0173)\end{array}$ \\
\hline feduc & $\begin{array}{c}-0.0108 \\
(0.0173)\end{array}$ & $\begin{array}{c}-0.0105 \\
(0.0172)\end{array}$ & $\begin{array}{c}-0.0126 \\
(0.0174)\end{array}$ & $\begin{array}{c}-0.0126 \\
(0.0173)\end{array}$ \\
\hline meduc & $\begin{array}{c}0.0772 * \\
(0.0220)\end{array}$ & $\begin{array}{c}0.0799 \star \\
(0.0218)\end{array}$ & $\begin{array}{c}0.0790 * \\
(0.0221)\end{array}$ & $\begin{array}{c}0.0805 * \\
(0.0218)\end{array}$ \\
\hline seduc & $\begin{array}{c}0.0114 \\
(0.0094)\end{array}$ & $\begin{array}{c}0.0136 \\
(0.0094)\end{array}$ & $\begin{array}{c}0.0103 \\
(0.0094)\end{array}$ & $\begin{array}{c}0.0112 \\
(0.0094)\end{array}$ \\
\hline oldest & $\begin{array}{c}0.0098 \\
(0.0134)\end{array}$ & $\begin{array}{c}0.0102 \\
(0.0134)\end{array}$ & $\begin{array}{c}0.0085 \\
(0.0134)\end{array}$ & $\begin{array}{c}0.0104 \\
(0.0134)\end{array}$ \\
\hline sibli & $\begin{array}{c}0.0096 * \\
(0.0030)\end{array}$ & $\begin{array}{c}0.0094 * \\
(0.0030)\end{array}$ & $\begin{array}{c}0.0093 * \\
(0.0030)\end{array}$ & $\begin{array}{c}0.0095 * \\
(0.0030)\end{array}$ \\
\hline Firm & Yes & Yes & Yes & Yes \\
\hline Job & Yes & Yes & Yes & Yes \\
\hline Year & Yes & Yes & Yes & Yes \\
\hline YI & Yes & Yes & Yes & Yes \\
\hline$R-s q$ & 0.514 & 0.516 & 0.513 & 0.516 \\
\hline
\end{tabular}

Note: esojt=edyear*sojt; esoff=edyear*soff; edten98=edyear*ten98; edexp=edyear*exp98; trint=soff*sojt; ojtpro=sojt*promo; offpro=soff*promo; esfrojt=edyear*sfojt; esfroff= edyear*sfroff; trintf=sfrojt*sfoff; frojtpr=frojt*promo; froffpr=froff*promo. See Table 4.

\section{c) Summary of the evidence}

The evidence from incidence regressions points to a negative correlation between educational attainment and OJT and to the absence of a significant correlation between attainment and OFFJT. On the other hand, the evidence from wage regressions suggests the presence of technical complementarity between education and both types of training. This evidence is somewhat stronger for OFFJT than for OJT. 


\section{Discussion and Conclusions}

In the second section of the paper, we have presented two simple economic models, both predicting that optimal training investment is obtained when the marginal costs and the marginal benefits of training are equal. Changes in educational attainment could affect optimal investment by affecting either marginal costs or marginal benefits or both. Model B in particular suggests that the marginal cost of training is proportional to the wage. Since individuals with more education have a higher opportunity value of time, they have also higher marginal training costs. Therefore, their marginal costs schedule lies to the left of the schedule associated to individuals with less education.

A shift from lower to higher education also affects marginal benefits, because of the complementarity between education and training. This complementarity is empirically stronger for OFFJT than for OJT. It follows that individuals with higher education have a marginal benefits schedule which lies to the right of the schedule accruing to less educated individuals. Moreover, the outward shift is quantitatively larger for OFFJT.

The overall effect of these shifts on training incidence is illustrated in Figures 2 and 3 below. In the case of OJT, the shift in the marginal costs schedule is relatively larger than the shift in the marginal benefits schedule and training incidence falls for the better educated. In the case of OFFJT, however, the relative shift of the marginal benefits schedule is bigger, so that on balance training incidence does not change in a significant way.

We can strengthen this interpretation by relying on additional factors affecting training costs. For instance, we could argue that the more educated have higher learning skills in more general and formalized OFFJT than in specific and often narrow OJT, because general education is more akin to formal off the job training. If this is the case, the outward shift in the training costs schedule for the more educated is smaller in the case of OFFJT than in the case of OJT. The important fact is that, in either cases, the marginal costs of training must be higher for the more educated. This is clearly in contrast with the literature reviewed in the introduction, which relies on the untested assumption that more education reduces marginal training costs. If anything, our data require the opposite to occur.

Our findings from wage regressions also suggest that training events increase future wages. Since average wages are related to labor productivity, we conclude that an increase in human capital, both via education and via training, positively affects labor productivity. Training affects future wages both directly and indirectly. The indirect effect occurs via promotion. We have shown that promotion records affect current wages. Not reported in the paper, a probit estimate of the probability of promotion shows 
that this probability is significantly and positively affected by both off the job and on the job training events. Therefore, training events can affect wages and productivity by influencing the probability of promotion.

The impact of educational attainment on wage and labor productivity is also both direct and indirect. To the direct and familiar effect one should add the indirect effect via training incidence: by affecting the investment in training, education influences the additional accumulation of human capital and future wages and productivity. An important result of this paper is that the direction of the indirect effect is likely to be negative, as OJT falls for the better educated and OFFJT remains more or less unchanged.

Our results have also implications for the specific case of Thailand. First, we have found that the direct returns to education are much smaller than previously found in the literature. This of course could depend on the fact that we are using a relatively small sample of large firms in four selected industries. In this sample, the returns to one year of additional education is close to 5 percent, close to the average return found in OECD developed countries ${ }^{8}$.

The negative relationship between educational attainment and OJT suggests that the firms in the sample have compensated the relative scarcity of human capital represented by low education with higher investment in on the job training. This compensation might have been necessary, given the rapid growth of manufacturing in Thailand during the past twenty years, which has by far outpaced the growth of educational attainment. In a way, such a policy may have helped reducing the initial differences in accumulated human capital, which are significantly related to differences in family background.

One fourth of the companies in our sample are Japanese subsidiaries. We conclude this paper by asking whether these firms provide significantly more training that domestic and other foreign subsidiaries. We investigate empirically this issue by retrieving the estimated coefficients associated to the firm dummies and by regressing these coefficients on a Japan dummy taking the value of one if the firm is a Japanese subsidiary and of zero otherwise. We use weighted least squares, with each weight defined as the inverse of the variance of the estimated coefficient. It turns out that Japan dummy is positive and significantly different from zero only in the case of OFFJT. This result runs counter the standard intuition that Japanese firms provide more intense on the job training (see Koike [1988]).

\footnotetext{
${ }^{8}$ According to Psacharopoulos [1994], the average rate of return to one year of education in the OECD is 6.8 percent. More recent research shows that the average rate of return in Europe is close to 5 percent (see Harmon, Nielsen and Walker [2000].
} 


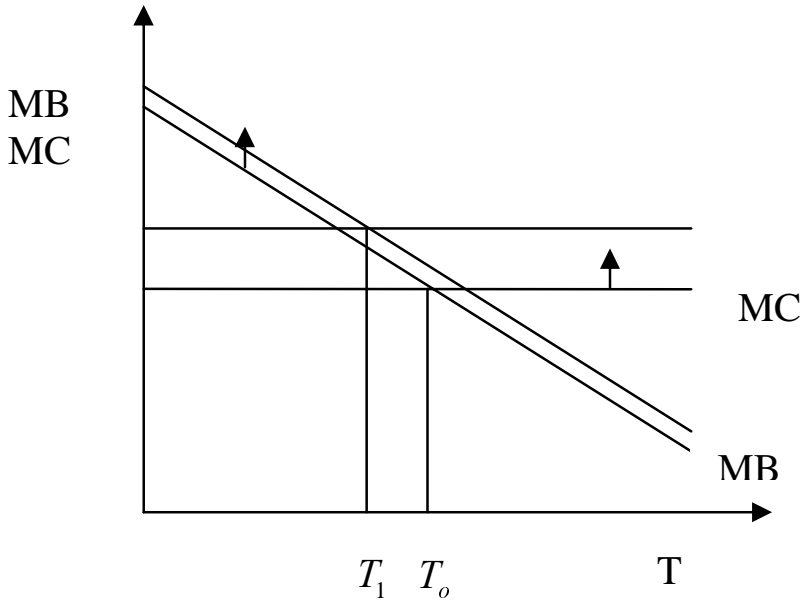

Figure 2. OJT

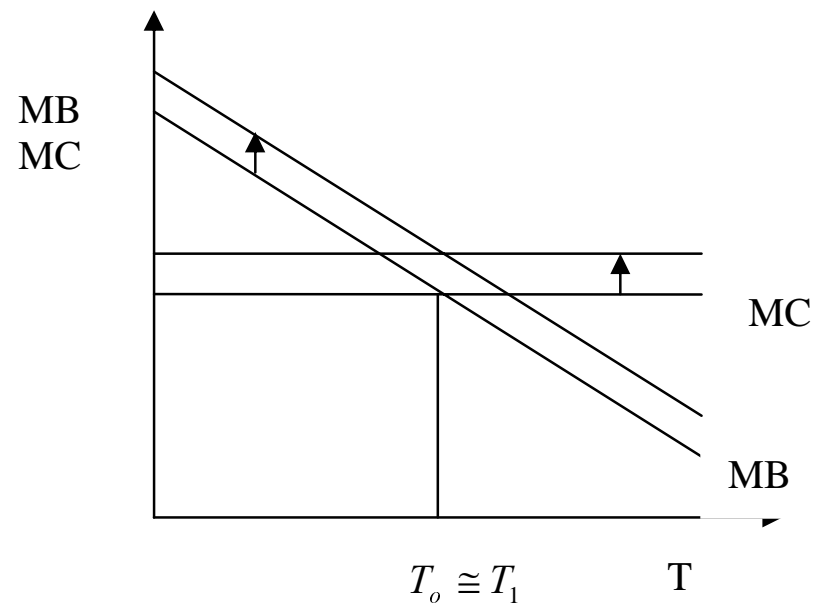

Figure 3. OFFJT 


\section{References}

Beckett, M. et al [2001], Measurement Errors in Recall Data, Journal of Human Resources, $3,36,593-624$.

Berhman, J. [1987], Schooling in Developing Countries: Which Countries are the Over and Underachievers and What is the Schooling Impact?, Economics of Education Review, 2, 6, 111-127.

Card, D., [1999], The Economic Returns to Education, in Ashenfelter, O. and Card, D., [1999], Handbook of Labor Economics, Volume 3, North Holland, Amsterdam.

Doner, R. and Brimble, P., [1998], Thainland's Hard Disk Drive Industry, Report 98-02, University of California at San Diego.

Greene, W., [1993], Econometric Analysis, McGraw Hill, New York.

Harmon, C., Nielsen, N. and Walker, I., [2000], The Returns to Education in Europe, Edward Elgar.

Hersch, R. [1991], Education Match and Job Match, The Review of Economics and Statistics, $73,1,140.44$,

Koike, K. [1988], Understanding Industrial Relations in Japan, MacMillan, London.

Psacharopoulos, G., [1994], Returns to Investment in Education: A Global Update, World Development, 22. 9, 1325-1343

Rosen, S. [1976], A Theory of Lifetime Earnings, Journal of Political Economy.

Sicherman, N., [1990], "Overeducation" in the Labor Market, Journal of Labor Economics, $9,2,101-122$

Thurow, L [1975], Generating Inequality, New York, Basic Books

Willis, R. [1986], Wage Determinants, in Ashenfelter, O. and Layard, R., $\underline{\text { Handbook of }}$ Labor Economics, North Holland, Amsterdam 


\section{IZA Discussion Papers}

\begin{tabular}{|c|c|c|c|c|}
\hline No. & Author(s) & Title & Area & Date \\
\hline 563 & $\begin{array}{l}\text { T. Dunne } \\
\text { L. Foster } \\
\text { J. Haltiwanger } \\
\text { K. R. Troske }\end{array}$ & $\begin{array}{l}\text { Wage and Productivity Dispersion in U.S. } \\
\text { Manufacturing: The Role of Computer } \\
\text { Investment }\end{array}$ & 5 & $08 / 02$ \\
\hline 564 & $\begin{array}{l}\text { J. D. Brown } \\
\text { J. S. Earle }\end{array}$ & $\begin{array}{l}\text { The Reallocation of Workers and Jobs in } \\
\text { Russian Industry: New Evidence on Measures } \\
\text { and Determinants }\end{array}$ & 4 & 09/02 \\
\hline 565 & $\begin{array}{l}\text { H. L. van Kranenburg } \\
\text { F. C. Palm } \\
\text { G. A. Pfann }\end{array}$ & $\begin{array}{l}\text { Survival in a Concentrating Industry: The Case } \\
\text { of Daily Newspapers in the Netherlands }\end{array}$ & 3 & 09/02 \\
\hline 566 & $\begin{array}{l}\text { R. Hujer } \\
\text { M. Caliendo } \\
\text { D. Radić }\end{array}$ & $\begin{array}{l}\text { Skill Biased Technological and Organizational } \\
\text { Change: Estimating a Mixed Simultaneous } \\
\text { Equation Model Using the IAB Establishment } \\
\text { Panel }\end{array}$ & 5 & 09/02 \\
\hline 567 & $\begin{array}{l}\text { H. Lehmann } \\
\text { K. Phillips } \\
\text { J. Wadsworth }\end{array}$ & $\begin{array}{l}\text { The Incidence and Cost of Job Loss in a } \\
\text { Transition Economy: Displaced Workers in } \\
\text { Estonia, 1989-1999 }\end{array}$ & 4 & 09/02 \\
\hline 568 & $\begin{array}{l}\text { H. O. Duleep } \\
\text { D. J. Dowhan }\end{array}$ & $\begin{array}{l}\text { Revisiting the Family Investment Model with } \\
\text { Longitudinal Data: The Earnings Growth of } \\
\text { Immigrant and U.S.-Born Women }\end{array}$ & 1 & 09/02 \\
\hline 569 & $\begin{array}{l}\text { J. Haltiwanger } \\
\text { M. Vodopivec }\end{array}$ & $\begin{array}{l}\text { Worker Flows, Job Flows and Firm Wage } \\
\text { Policies: An Analysis of Slovenia }\end{array}$ & 4 & 09/02 \\
\hline 570 & $\begin{array}{l}\text { T. K. Bauer } \\
\text { S. Bender }\end{array}$ & $\begin{array}{l}\text { Technological Change, Organizational } \\
\text { Change, and Job Turnover }\end{array}$ & 1 & 09/02 \\
\hline 571 & $\begin{array}{l}\text { O. Ashenfelter } \\
\text { M. Greenstone }\end{array}$ & $\begin{array}{l}\text { Using Mandated Speed Limits to Measure the } \\
\text { Value of a Statistical Life }\end{array}$ & 5 & 09/02 \\
\hline 572 & $\begin{array}{l}\text { C. Y. Co } \\
\text { I. N. Gang } \\
\text { M.-S. Yun }\end{array}$ & $\begin{array}{l}\text { Self-Employment and Wage Earning: } \\
\text { Hungary During Transition }\end{array}$ & 4 & 09/02 \\
\hline 573 & $\begin{array}{l}\text { R. T. Riphahn } \\
\text { O. Serfling }\end{array}$ & $\begin{array}{l}\text { Item Non-Response on Income and Wealth } \\
\text { Questions }\end{array}$ & 6 & $09 / 02$ \\
\hline 574 & $\begin{array}{l}\text { R. Kuhn } \\
\text { S. Stillman }\end{array}$ & $\begin{array}{l}\text { Understanding Interhousehold Transfers in a } \\
\text { Transition Economy: Evidence from Russia }\end{array}$ & 4 & 09/02 \\
\hline 575 & $\begin{array}{l}\text { H. Antecol } \\
\text { D. A. Cobb-Clark } \\
\text { S. J. Trejo }\end{array}$ & $\begin{array}{l}\text { Human Capital and Earnings of Female } \\
\text { Immigrants to Australia, Canada, and the } \\
\text { United States }\end{array}$ & 5 & 09/02 \\
\hline 576 & $\begin{array}{l}\text { M. Fertig } \\
\text { C. M. Schmidt } \\
\text { H. Schneider }\end{array}$ & $\begin{array}{l}\text { Active Labor Market Policy in Germany - } \\
\text { Is There a Successful Policy Strategy? }\end{array}$ & 6 & 09/02 \\
\hline 577 & $\begin{array}{l}\text { K. Ariga } \\
\text { G. Brunello }\end{array}$ & $\begin{array}{l}\text { Are the More Educated Receiving More } \\
\text { Training? Evidence from Thailand }\end{array}$ & 2 & 09/02 \\
\hline
\end{tabular}

An updated list of IZA Discussion Papers is available on the center's homepage www.iza.org. 